\title{
Expression of peroxisome proliferator-activated receptor (PPAR) $\gamma$ in gastric cancer and inhibitory effects of PPAR $\gamma$ agonists
}

\author{
H Sato', S Ishihara', K Kawashima', N Moriyama', H Suetsugu'1, H Kazumori', T Okuyama', MAK Rumi', R Fukuda', \\ N Nagasue ${ }^{2}$ and Y Kinoshita ${ }^{1}$
}

${ }^{1}$ Second Department of Internal Medicine; ${ }^{2}$ Second Department of Surgery, Shimane Medical University, Izumo, Shimane, Japan

Summary Peroxisome proliferator-activated receptor (PPAR) $\gamma$ is expressed in human colon cancer, prostate cancer and breast cancer cells, and PPAR $\gamma$ activation induces growth inhibition in these cells. PPAR $\gamma$ expression in human gastric cancer cells, however, has not been fully investigated. We report the PPAR $\gamma$ expression in human gastric cancer, and the effect of PPAR $\gamma$ ligands on proliferation of gastric carcinoma cell lines. Immunohistochemistry was used to demonstrate the presence of PPAR $\gamma$ protein in surgically resected specimens from well differentiated, moderately differentiated and poorly differentiated adenocarcinoma. We used reverse transcription-polymerase chain reaction and Northern and Western blot analyses to demonstrate PPAR $\gamma$ expression in four human gastric cancer cell lines. PPAR $\gamma$ agonists (troglitazone and 15-deoxy- $\Delta^{12,14}$-prostaglandin J2) showed dose-dependent inhibitory effects on the proliferation of the gastric cancer cells, and their effect was augmented by the simultaneous addition of 9-cis retinoic acid, a ligand of RXR $\alpha$. Flow cytometry demonstrated G1 cell cycle arrest and a significant increase of annexin V-positive cells after treatment with troglitazone. These results suggest that induction of apoptosis together with G1 cell cycle arrest may be one of the mechanisms of the antiproliferative effect of PPAR $\gamma$ activation in human gastric cancer cells. () 2000 Cancer Research Campaign

Keywords: PPAR $\gamma$, gastric cancer; growth inhibition; apoptosis

Thiazolidinediones, including troglitazone, and 15 -deoxy- $\Delta^{12,14}$ prostaglandin J2 (15d-PGJ2), a metabolite of prostaglandin J, have been identified as ligands for peroxisome proliferator-activated receptor (PPAR) $\gamma$ (Forman et al, 1995; Kliewer et al, 1995). PPAR $\gamma$ has been reported to play an important role in insulin sensitization and adipocyte (Chawla et al, 1994) and monocyte/macrophage (Tontonoz et al, 1998; Pelton et al, 1999) differentiation. Expression and activation of PPAR $\gamma$ in fibroblastic and myoblastic cells triggers the adipocyte gene expression cascade and leads to the development of the adipose phenotype (Tontonoz et al, 1994; Hu et al, 1995). This receptor and its heterodimeric partner, retinoid $\mathrm{X}$ receptor $(\mathrm{RXR}) \alpha$, which binds to 9-cis retinoic acid (9-cis RA), form a DNA-binding complex. Transcriptional activity of the PPAR $\gamma / \mathrm{RXR} \alpha$ heterodimer is maximal in the presence of both PPAR $\gamma$ and RXR $\alpha$ activators (Mukherjee et al, 1997). Recent reports have indicated that PPAR $\gamma$ also express in different tissues and PPAR $\gamma$ ligands can induce growth inhibition in human prostate cancer cells (Kubota et al, 1998), colon cancer cells (Brockman et al, 1998; Sarraf et al, 1998; Kitamura et al, 1999) and liposarcoma cells (Tontonoz et al, 1997). Induction of apoptosis by PPAR $\gamma$ has been demonstrated in mammalian cells (Elstner et al, 1998; Clay et al, 1999; Keelan et al, 1999). A recent study has demonstrated expression of PPAR $\gamma$ in human gastric cancer cell line MKN45 and reported

Received 15 February 2000

Revised 10 July 2000

Accepted 12 July 2000

Correspondence to: $\mathrm{H}$ Sato troglitazone-induced growth inhibition and apoptosis (Takahashi et al, 1999). To evaluate the possibility of PPAR $\gamma$ ligands in gastric cancer treatment, in the present study we have investigated PPAR $\gamma$ expression in human gastric carcinoma tissues and checked growth inhibitory effects of different types of PPAR $\gamma$ agonists on four cell lines.

\section{MATERIALS AND METHODS}

\section{Immunohistochemistry for PPAR $\gamma$ protein}

Human gastric cancer tissues were obtained at the time of surgical removal with the informed consent of the patients. The corresponding normal gastric tissues were also obtained simultaneously. These samples were immediately frozen and stored in liquid nitrogen until immunohistochemistry. Identification of cancer and non-cancer specimens was confirmed by light microscopic examination. From these samples, 3- $\mu \mathrm{m}$ thick cryostat tissue sections were mounted on poly-L-lysine-coated slides and stored at $-20^{\circ} \mathrm{C}$. The slides were air-dried for $30 \mathrm{~min}$ and fixed in acetone at $-4^{\circ} \mathrm{C}$ for $10 \mathrm{~min}$. Samples were then incubated with normal horse serum (Vector Laboratories, Burlingame, CA, USA) for $30 \mathrm{~min}$, followed by incubation with a mouse monoclonal antibody recognizing human PPAR $\gamma$ (Santa Cruz Biotechnology, Santa Cruz, CA, USA) for $120 \mathrm{~min}$. Mouse IgG1 myeloma protein MOPC-21 (Sigma, St Louis, MO, USA) was used as control. After washing the sections with phosphate buffered saline (PBS), they were incubated with biotinylated horse anti-mouse IgG (Vector Laboratories) for $30 \mathrm{~min}$. Bound antibody was detected using the avidin-biotin peroxidase method (ABC Kit; Vector Laboratories). Peroxidase 
activity was subsequently detected by 3,3'-diaminobenzidine (Sigma) in $0.05 \mathrm{M}$ Tris- $\mathrm{HCl}$ for $10 \mathrm{~min}$ at room temperature, followed by haematoxylin staining. After dehydration in a graded alcohol series, the sections were cleared in xylene.

\section{Cell lines}

Four human gastric cancer cell lines, MKN-7, MKN-28, MKN-45 and AGS were used in this study. MKN-7, MKN-28 and MKN-45 were obtained from Riken Cell Bank (Ibaraki, Japan) and AGS from the American Type Culture Collection (ATCC, Rockville, MD, USA). The MKN-45 and AGS were established from poorly differentiated gastric carcinoma and $\mathrm{MKN}-7$ and $\mathrm{MKN}-28$ from well and moderately differentiated gastric carcinoma. MKN-7, MKN-28 and MKN-45 cells were cultured in RPMI 1640 (ICN Biomedicals, Ohio, USA) and AGS cells in Ham's F12 (ICN) supplemented with $10 \%$ fetal bovine serum in an atmosphere of $5 \% \mathrm{CO}_{2}$ at $37^{\circ} \mathrm{C}$ in a humidified incubator.

\section{RNA extraction}

Total RNA was extracted by the acid guanidinium phenol chloroform method using Isogen (Nippon Gene, Tokyo, Japan). $5 \times 10^{6}$ cells were shaken vigorously for $1 \mathrm{~min}$ in $0.8 \mathrm{ml}$ of Isogen solution and $0.2 \mathrm{ml}$ of chloroform. After centrifugation at $12000 \mathrm{rpm}$ at $4^{\circ} \mathrm{C}$ for $15 \mathrm{~min}$, the aqueous phase was transferred to a fresh tube, an equal volume of isopropanol was added and the mixture was allowed to stand at $4^{\circ} \mathrm{C}$ for $15 \mathrm{~min}$, followed by centrifugation at $12000 \mathrm{rpm}$ at $4^{\circ} \mathrm{C}$ for $15 \mathrm{~min}$. The RNA precipitate was rinsed with $75 \%$ ethanol and air-dried for $5 \mathrm{~min}$. Finally, RNA was dissolved in $50 \mu \mathrm{l}$ of distilled water containing $0.1 \%$ diethylpyrocarbonate and the RNA concentration was measured by spectrophotometry at $260 \mathrm{~nm}$.

\section{Reverse transcription-polymerase chain reaction}

Five $\mu g$ total RNA extracted from each cell line was reverse transcribed to cDNA using a First Strand cDNA Synthesis Kit (Stratagene, Toyobo, Japan) according to the manufacturer's instructions using oligo (dT) primer. Synthesized cDNA was stored at $-80^{\circ} \mathrm{C}$ until used for the polymerase chain reaction assay (PCR). The primers used for amplifying PPAR $\gamma$ cDNA were 5'-TCTGGCCCACCAACTTTGGG-3' and 5'-CTTCACAAGCATGAACTCCA- $3^{\prime}$ and for RXR $\alpha$ cDNA were 5'-CTCTCAGGTTGAACTCACCT-3' and 5'-ATCTCTGACAGCCTGTCTCG-3'. As internal control, RT-PCR for $\beta$-actin mRNA was also performed using the primers (5'-ATCTGGCACCACACCTTCTACAATGAGCTGCG-3' and 5'-CGTCATACTCCTGCTTGCTGATCCACATCTGC-3'). After denaturation of the samples at $95^{\circ} \mathrm{C}$ for $10 \mathrm{~min}, \mathrm{PCR}$ was carried out in a DNA thermal cycler (PE Biosystems, Foster City, CA, USA) for 35 cycles $\left(95^{\circ} \mathrm{C}\right.$ for $1 \mathrm{~min}, 55^{\circ} \mathrm{C}$ for $30 \mathrm{~s}$ and $72^{\circ} \mathrm{C}$ for $1 \mathrm{~min}$ ) followed by $72^{\circ} \mathrm{C}$ for $10 \mathrm{~min}$. $5 \mu \mathrm{l}$ of PCR products were electrophoresed in $1 \%$ agarose gels stained with ethidium bromide. The detection of amplified DNA bands at the expected lengths (PPAR $\gamma 360$ bp, RXR $\alpha 422$ bp, $\beta$-actin 838 bp) was confirmed and products were also directly sequenced by ABI Prism 310 Genetic Analyser using BigDye terminator Cycle Sequencing Reagent (PE Biosystems).

\section{Northern blot analysis}

From each cell line, $20 \mu \mathrm{g}$ total RNA was electrophoresed in formaldehyde-containing $1.2 \%$ agarose gels and transferred to a nitrocellulose membrane (Schleicher and Schuell, Dassel, Germany), followed by fixation with UV cross-linker (FunaUV-Linker; Funakoshi, Tokyo, Japan). The probes used for Northern blot analysis were a ${ }^{32} \mathrm{P}$-labelled $360 \mathrm{bp}$ cDNA fragment of human PPAR $\gamma$ and a ${ }^{32}$ P-labelled 838 bp cDNA fragment of human $\beta$-actin. After $4 \mathrm{~h}$ prehybridization and $24 \mathrm{~h}$ hybridization at $42^{\circ} \mathrm{C}$, the filters were washed first for $10 \mathrm{~min}$ and then for $15 \mathrm{~min}$ at $37^{\circ} \mathrm{C}$ in $2 \times$ saline-sodium citrate (SSC) containing $0.2 \%$ sodium dodecyl sulphate (SDS), and finally at $50^{\circ} \mathrm{C}$ in $0.1 \times \mathrm{SSC}$ containing $0.2 \%$ SDS for $20 \mathrm{~min}$. Autoradiography was performed using image analyser BAS 2000 II (Fuji Photo Film Co, Tokyo, Japan).

\section{Western blot analysis}

Protein concentrations were measured using Bio-Rad Protein Assay Reagent (Bio-Rad Laboratories, Richmond, CA, USA) following the manufacturer's instruction. $50 \mu \mathrm{g}$ of protein was separated by $10 \%$ SDS PAGE. After electrophoresis, the proteins were transferred to polyvinylidene membranes (Amersham International, Buckingham, UK), blocked in TBS-Tween with $10 \%$ skimmed milk at $4^{\circ} \mathrm{C}$ for $1 \mathrm{~h}$, subsequently reacted with primary monoclonal antibody overnight and washed. After reacting with a mouse peroxidase-conjugated antibody detection agent (Amersham), signal was detected by chemiluminescence using the ECL detection system (Amersham). For detection of PPAR $\gamma$, mouse anti-human PPAR $\gamma$ monoclonal antibody (SC-7273, Santa Cruz) was used. As an internal control, $\beta$-actin was detected with mouse monoclonal antibody (AC-15, Sigma).

\section{Growth assessment and chemicals}

Human gastric cancer cells were seeded $\left(1 \times 10^{5}\right.$ cells $\left.\mathrm{ml}^{-1}\right)$ in 24-well plates and treated for $48 \mathrm{~h}$ with each chemical agent. Troglitazone was kindly provided by Sankyo Pharmaceutical Co (Tokyo, Japan) and dissolved in dimethyl sulphoxide (DMSO). Indomethacin (Nacalai tasque, Kyoto, Japan) was also dissolved in DMSO. 9-cis RA (Sigma) and 15d-PGJ2 (Calbiochem, La Jolla, CA, USA) were dissolved in ethanol. Vehicle in the medium did not exceed $0.1 \%$. After $48 \mathrm{~h}$ treatment with drug, $1 \mu \mathrm{Ci}$ [Methyl${ }^{3} \mathrm{H}$ ] thymidine (Amersham) was added to each well and incubated for $4 \mathrm{~h}$. Cells were harvested onto a glass fibre filter mat using a Cell Harvester (Inotech, Switzerland). After the mat was dried $\left[{ }^{3} \mathrm{H}\right]$ thymidine incorporation was measured by 1450 Microbeta scintillation counter (Wallac, Oy, Turku, Finland). Assessment of cell proliferation was performed in triplicate and repeated three times.

\section{Cell cycle analysis}

Cell cycle profiles were performed on all four gastric cancer cell lines. Cells were treated with $10 \mu \mathrm{M}$ troglitazone for $48 \mathrm{~h}$, collected after brief trypsinization, washed with PBS, and fixed in cold $70 \%$ ethanol. Then the samples were treated with RNase, stained with $50 \mu \mathrm{g} \mathrm{ml}^{-1}$ propidium iodide (PI), and analysed by EPICS Elite flow cytometer (Coulter Electronics, FL, USA). 


\section{Detection of apoptosis in gastric cancer cells}

To detect apoptotic cells, the expression of annexin $\mathrm{V}$ on the cell surface was examined by flow cytometry. Annexin V detects phosphatidylserine on the outer cytoplasmic membrane, which occurs during the loss of phospholipid asymmetry early in the apoptotic process. After $48 \mathrm{~h}$ treatment with troglitazone, the supernatant was removed and the adherent cells were harvested with $0.05 \%$ trypsin. The cells were washed three times with PBS and incubated with FITC-conjugated annexin V antibody (Immunotech, Marseille, France) and PI in medium containing $1.5 \mathrm{mM} \mathrm{CaCl}_{2}$ at $4^{\circ} \mathrm{C}$ for $15 \mathrm{~min}$. After incubation, cells were analysed by flow cytometry (FACScan; Becton Dickinson, San Jose, CA, USA). The assay was done in triplicate and repeated three times. PInegative and annexin V-positive cells were considered as early apoptotic cells.

Nuclear morphology of apoptosis was assessed by staining with Hoechst 33258 (Calbiochem); cells with condensed or fragmented nuclei were recognized as apoptotic cells by fluorescence microscopy (Olympus, Tokyo, Japan).

\section{Statistical analysis}

Data are expressed as means \pm SE. Values were compared and significant differences between means were determined by Analysis of variance (ANOVA). Multiple comparisons were done by Sheff's test after ANOVA and $P$ values $<0.05$ were considered statistically significant.

\section{RESULTS}

\section{Expression of PPAR $\gamma$ protein in human gastric cancer}

Surgically obtained tissue from gastric adenocarcinoma expressed PPAR $\gamma$ protein, as shown by immunohistochemistry (Figure 1). We stained sections from 12 selected cases - four poorly differentiated, four moderately differentiated and four poorly differentiated cancers. The staining result was consistent in all cases. PPAR $\gamma$ protein was expressed not only in well differentiated, moderately differentiated and poorly differentiated gastric adenocarcinoma, but also normal mucosa with intestinal metaplasia adjacent to cancer.

\section{PPAR $\gamma$ and $R X R \alpha$ expression in human gastric cancer cell lines}

We used RT-PCR to determine the expression of PPAR $\gamma$ and RXR $\alpha$ mRNA in four gastric cancer cell lines: MKN-7, MKN-28, MKN-45 and AGS. As shown in Figure 2A, PPAR $\gamma$ and RXR $\alpha$ mRNA were expressed in all the four cell lines. PPAR $\gamma$ mRNA was expressed at relatively higher levels in MKN-7 and MKN-45 cells (Figure 2B). PPAR $\gamma$ protein was also detected in all four cell lines, but only at a low level in AGS cells. As an internal control, we demonstrated $\beta$ actin expression (Figure 2C).

\section{Growth assessment of human gastric cancer cell lines}

We evaluated the effect of various ligands on the proliferation of the four gastric cancer cell lines by $\left[{ }^{3} \mathrm{H}\right]$-thymidine incorporation. There was a dose-dependent reduction in $\left[{ }^{3} \mathrm{H}\right]$-thymidine uptake after treatment with troglitazone for $48 \mathrm{~h}$ in three cell lines,

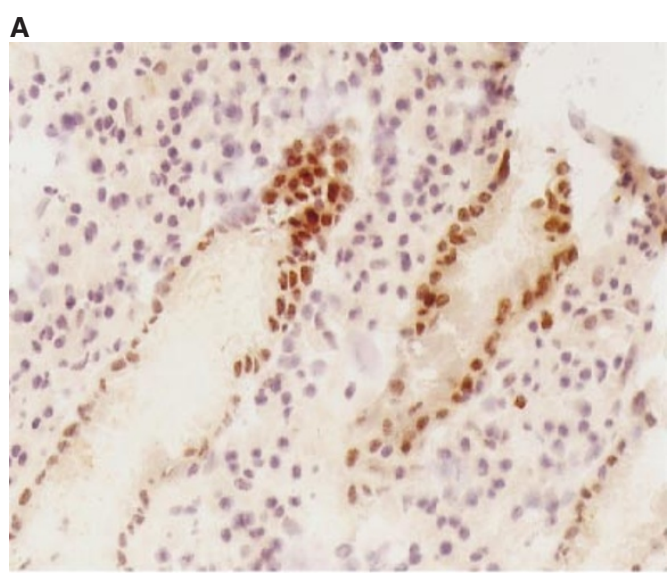

B
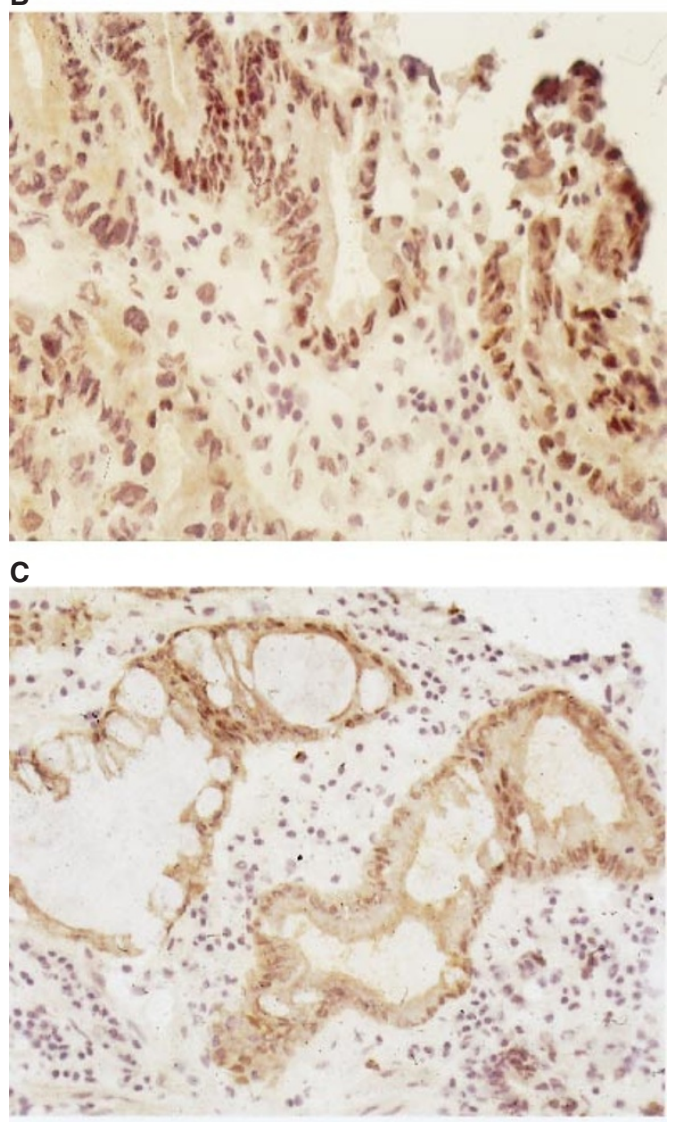

Figure 1 PPAR $\gamma$ protein expression in human gastric cancer tissues. PPAR $\gamma$ protein is expressed in both well differentiated $(\mathbf{A})$ and poorly differentiated (B) adenocarcinoma. In addition, PPAR $\gamma$ protein is also present in non-cancerous tissue with intestinal metaplasia (C) adjacent to cancer tissue

MKN-28, MKN-45, and AGS. Troglitazone induced a significant $(P<0.05)$ antiproliferative effect at a concentration of $10 \mu \mathrm{M}$ in these cell lines. Treatment with $15 \mathrm{~d}-\mathrm{PGJ} 2$, a natural ligand for PPAR $\gamma$, also reduced $\left[{ }^{3} \mathrm{H}\right]$-thymidine uptake in MKN-45 and AGS cells. However, in MKN-7 cells, increased incorporation of $\left[{ }^{3} \mathrm{H}\right]-$ thymidine was observed after treatment with troglitazone or $15 \mathrm{~d}$ PGJ2. Indomethacin, a ligand for PPAR $\gamma$ (Lehmann et al, 1997), and 9-cis RA, a ligand for RXR $\alpha$, showed weak growth suppression at high concentrations (Figure 3), but their effects were 
A
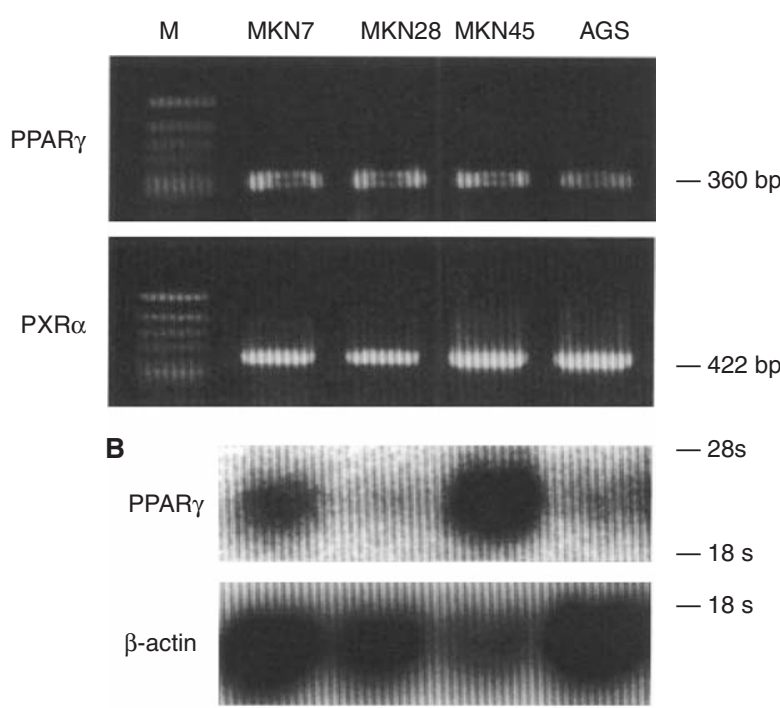

C

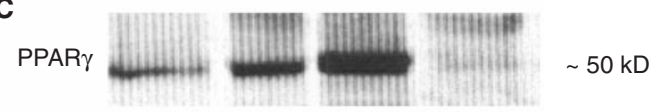

$\beta$-actin

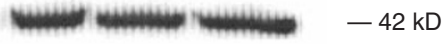

Figure 2 PPAR $\gamma$ expression in human gastric cancer cell lines. (A) PPAR $\gamma$ and RXR $\alpha$ expression at the mRNA level in human gastric cancer cell lines. From each cell line, $5 \mu \mathrm{g}$ of total RNA was subjected to RT-PCR. $5 \mu \mathrm{l}$ aliquot of the PCR products were electrophoresed in 1\% agarose gel. (B) Northern blot analysis of PPAR $\gamma$ expression in human gastric cancer cell lines. Approximately $20 \mu \mathrm{g}$ of RNA of each cell line was electrophoresed through formaldehyde-containing $1.2 \%$ agarose gels and transferred to a nitrocellulose membrane. Hybridization was performed using a human PPAR $\gamma$ cDNA probe labelled with $\left[\alpha-{ }^{32} P\right]$ dCTP. The $\beta$-actin level shown in the lower lane is to demonstrate that equivalent amounts of RNA were loaded on each lane. (C) PPAR $\gamma$ protein expression in human gastric cancer cell lines. Approximately $50 \mu \mathrm{g}$ of protein from each cell line was separated on an SDS-PAGE gel, probed with an anti-PPAR $\gamma$ antibody, and visualized with enhanced chemiluminescence. As an internal control, $\beta$-actin was detected

weaker than that of troglitazone. Furthermore, we tested the effect of simultaneous administration of ligands of PPAR $\gamma$ and RXR $\alpha$ on the proliferation of gastric cancer cells. As shown in Figure 4, 9cis RA augmented the growth inhibitory effect of troglitazone on gastric cancer cells. The experiment was also done on other cell lines and as the result was similar and there was no difference from PPAR $\gamma$ ligand response, detailed data are not shown.

\section{Changes of cell cycle profile by treatment with troglitazone}

To investigate the mechanism of growth inhibition by PPAR $\gamma$ activation, we performed flow cytometric analysis to test the effect of troglitazone on the cell cycle profile. Representative cell cycle profiles are shown in Figure 5. Troglitazone-treated MKN-28, MKN-45 and AGS cells exhibited a significant increase in G1 phase associated with a decrease in S phase. On the other hand, G1 phase decreased slightly with an $\mathrm{S}$ phase increase in MKN-7. These results suggest that activation of PPAR $\gamma$ usually inhibits most cellular growth via induction of cell cycle arrest in G1,
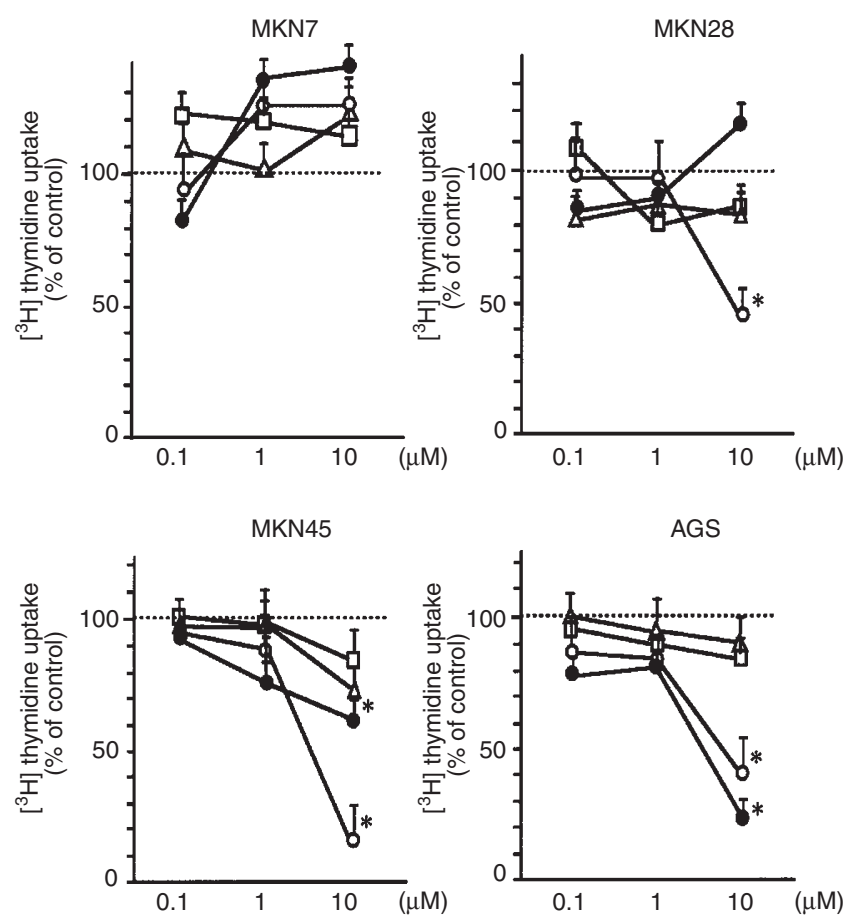

Figure 3 Dose-dependent effect of troglitazone and 15d-PGJ2 on growth inhibition in human gastric cancer cell lines. Cells were seeded into 24-well plates at a density of $1 \times 10^{5}$ cells well ${ }^{-1}$ and treated with troglitazone, 9-cis $\mathrm{RA}$, indomethacin and $15 \mathrm{~d}-\mathrm{PGJ} 2$. After culture for $48 \mathrm{~h}$, DNA synthesis was measured as $\left[{ }^{3} \mathrm{H}\right]$ thymidine incorporation. Results are expressed as a percentage of control and each point represents the mean \pm SE of three independent experiments. ${ }^{*} P<0.05$ compared with untreated control. $\bigcirc=$ troglitazone, $\square=9$-cis RA, $\triangle$ = indomethacin, $\mathbf{O}=15 \mathrm{~d}$-PGJ2

however, in some cell lines such as MKN-7, they may induce a proliferative response.

\section{Detection of apoptosis in human gastric cancer cells}

We evaluated whether PPAR $\gamma$ ligands induce apoptosis in human gastric cancer cells. Flow cytometric analysis was used to quantify apoptosis of cells treated with troglitazone $10 \mu \mathrm{M}$ for $48 \mathrm{~h}$. Treatment with troglitazone resulted in an increase of annexin V-positive cells in MKN-28, MKN-45, and AGS cells, but no increase in MKN-7 cells (Figure 6). As shown in Figure 7, we also confirmed morphologically the presence of apoptotic cells with condensed or fragmented nuclei by staining with Hoechst 33258.

\section{DISCUSSION}

PPAR $\gamma$, a subtype of the PPAR family, is predominantly expressed in adipose tissue, where it controls critical steps of lipid homeostasis and functions as a key trigger of adipocyte differentiation. PPAR $\gamma$ expression has also been found in cells from various lineages, such as liposarcoma, human breast cancer, colon cancer, and prostate cancer. Administration of PPAR $\gamma$ ligands was shown to inhibit the growth of these cells. In addition, a recent report demonstrated that in patients with advanced liposarcoma, troglitazone induced histological and biochemical differentiation of tumour cells to adipocytes (Demetri et al, 1999). These observations suggest that induction of terminal differentiation with PPAR $\gamma$ agonists may represent a novel therapeutic approach to human 


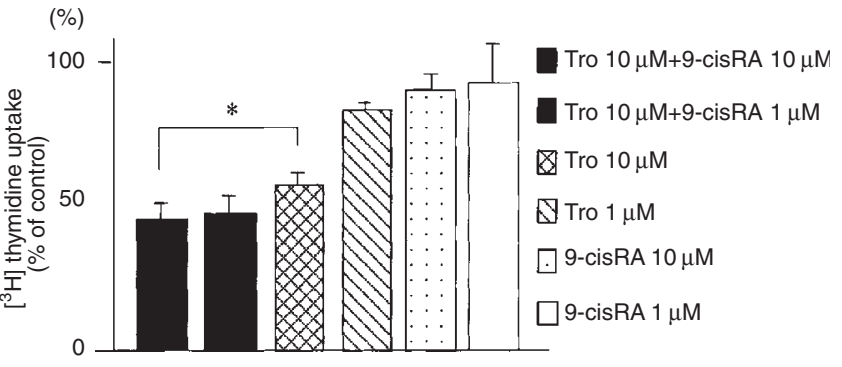

Figure 4 Effect of simultaneous treatment with troglitazone (TRO) and 9-cis RA on growth inhibition. AGS cells were seeded $\left(1 \times 10^{5}\right.$ cells well $\left.^{-1}\right)$ and treated with troglitazone and/or 9-cis RA. After culture for $48 \mathrm{~h},\left[{ }^{3} \mathrm{H}\right]$ thymidine incorporation was measured. Results are expressed as a percentage of control. ${ }^{*} P<0.05$ compared with untreated control

Control Troglitazone $(10 \mu \mathrm{M})$
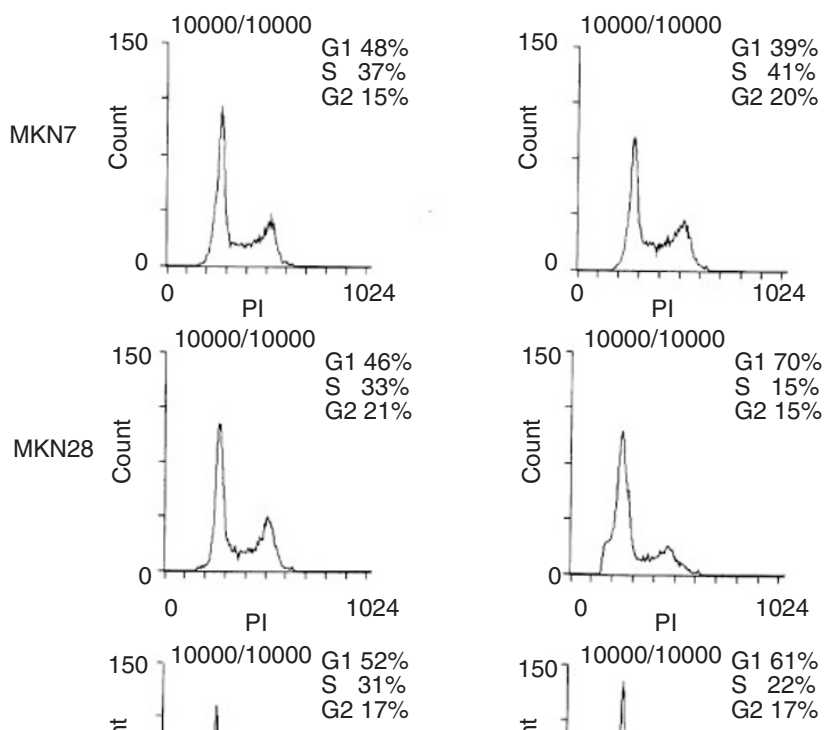

MKN45
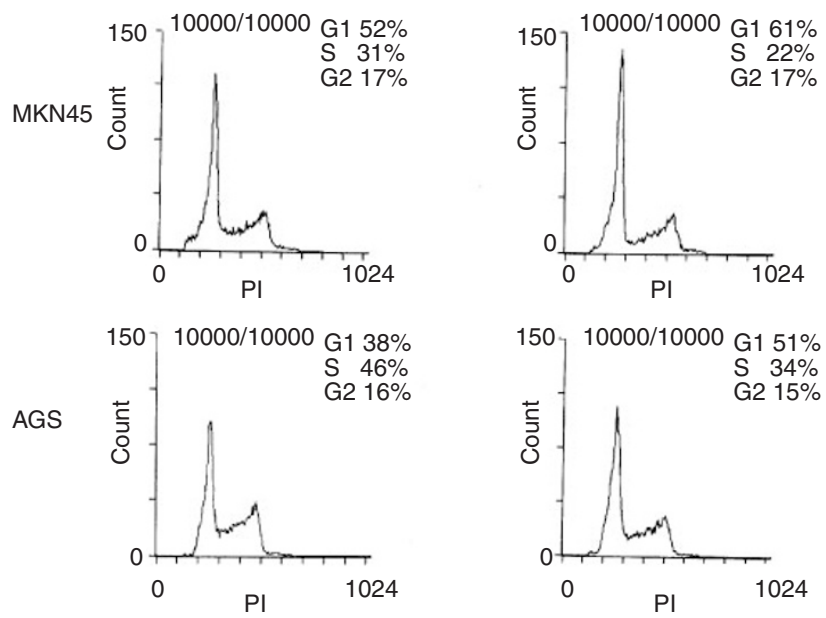

Figure 5 Effect of a PPAR $\gamma$ ligand on cell cycle profile. Cells were cultured in presence of troglitazone $(10 \mu \mathrm{M})$ or DMSO for $48 \mathrm{~h}$, then harvested, fixed, stained with $\mathrm{PI}$ and analysed by flow cytometry. The values represent the number of cells in a phase of the cell cycle as a percentage of total cells

malignancies. However, in colon cancer cells, the growth suppressing effect of PPAR $\gamma$ agonists, which was clearly shown in in vitro studies, was not necessarily confirmed by in vivo studies. Several reports have indicated that activation of PPAR $\gamma$ promotes
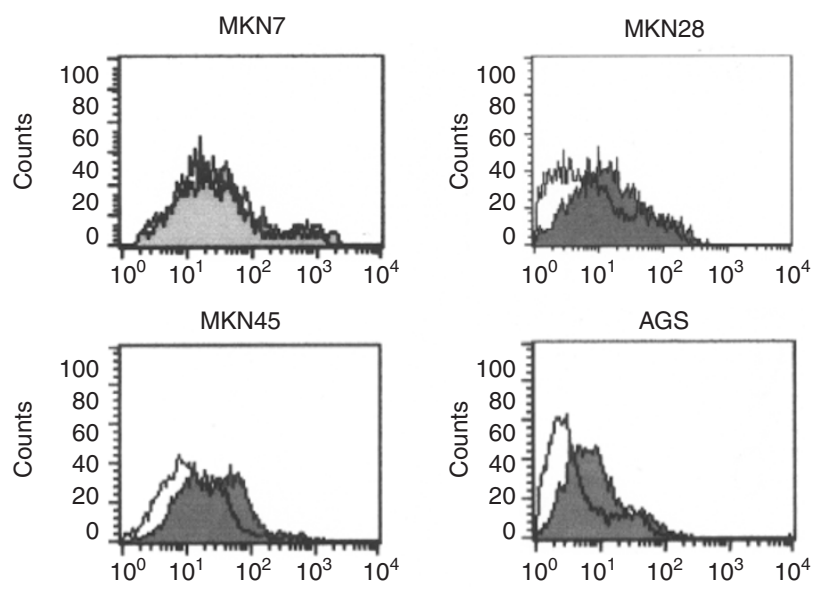

Control

Troglitazone $(10 \mu \mathrm{M})$

Figure 6 Effect of a PPAR $\gamma$ ligand on apoptosis of gastric cancer cells. Cells were incubated in presence of troglitazone $(10 \mu \mathrm{M})$ or DMSO for $48 \mathrm{~h}$, then harvested and incubated with FITC-conjugated annexin $\mathrm{V}$ antibody and $\mathrm{PI}$. Cells were analysed by flow cytometry; PI-negative and annexin $\mathrm{V}$-positive cells were considered as early apoptotic cells

the development of colon tumours, not only in $\mathrm{C} 57 \mathrm{BL} / 6 \mathrm{~J}-$ APCmin/+ mice, a clinically relevant model for human familial adenomatous polyposis, but also in animal models that develop sporadic colon cancer (Lefebvre et al, 1998; Saez et al, 1998).

The expression of PPAR $\gamma$ in human gastric cancer has not been fully elucidated. We found strong expression of PPAR $\gamma$ in surgically resected human gastric cancer specimens irrespective of the differentiation of the cancer tissue. Furthermore, gastric antral mucosa with intestinal metaplasia was also shown to express PPAR $\gamma$ protein. This is the first report showing the presence of PPAR $\gamma$ not only in gastric cancer but also in non-cancerous mucosa of human stomach. In addition, we demonstrated an antiproliferative effect of PPAR $\gamma$ ligands in vitro. A significant growth inhibitory effect of troglitazone or 15d-PGJ2 was observed only in moderately and poorly differentiated adenocarcinoma cell lines. Conversely, growth inhibition by these ligands was not found in a well differentiated adenocarcinoma cell line, MKN-7, even at higher concentrations. Therefore, the role of PPAR $\gamma$ in growth control of human gastric cancer cells may depend on cellular differentiation, and well differentiated cancers may lose their sensitivity to growth control by PPAR $\gamma$.

In this study, AGS cell line with low level PPAR $\gamma$ protein expression showed a significant antiproliferative effect, but MKN7 cells with high PPAR $\gamma$ expression did not. It seems difficult to explain the discrepancy between quantity of PPAR $\gamma$ protein expression and the anti-proliferative effect induced by PPAR $\gamma$ agonists on gastric carcinoma cell lines. Due to involvement of multiple factors like RXR $\alpha$, cofactors, hsp70, etc, in PPAR $\gamma$ activation and binding to PPAR $\gamma$-responsive element (PPRE), PPAR $\gamma$ agonist-mediated response may not depend only on the quantity of PPAR $\gamma$ protein present in a cell line. One possible explanation is PPAR $\gamma$ mutation in MKN7. Defect in other factors necessary for PPAR $\gamma$ activation and binding to PPAR $\gamma$-responsive element (PPRE), or defect in the target gene(s) after PPAR $\gamma$ activation should also be considered as another possibility for ineffective response in MKN-7. 


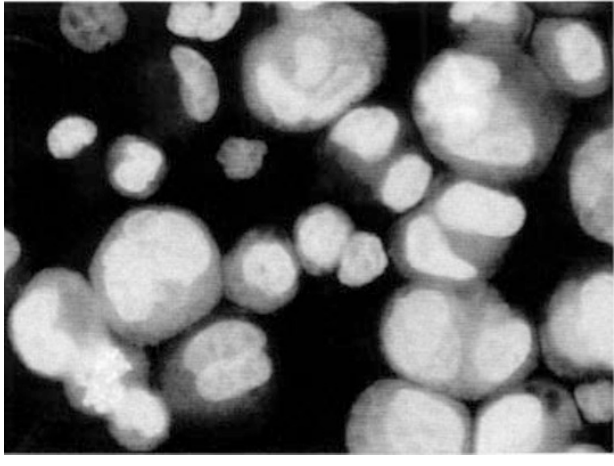

Control

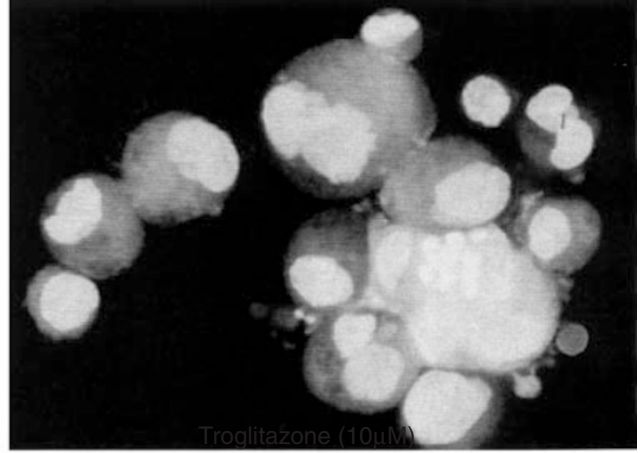

Troglitazone $(10 \mu \mathrm{M})$

Figure 7 Appearance of AGS cells with nuclear condensation and fragmentation after treatment with troglitazone for $48 \mathrm{~h}$. Cells were treated with troglitazone $(10 \mu \mathrm{M})$ or DMSO for $48 \mathrm{~h}$, the medium was removed, and the cells were fixed with $1.0 \%$ glutaraldehyde, stained with Hoechst 33258 dye and fluorescence visualized using a fluorescent microscope. The photomicrographs were taken at $\times 400$ magnification.

Although the mechanism of growth inhibition via PPAR $\gamma$ in human gastric cancer cells has not been fully elucidated, it may be connected to the cell cycle, as reported with other mammalian cells. In our study, G1 cell cycle arrest was observed in moderately differentiated MKN-28 cells and in poorly differentiated AGS and MKN-45 cells after treatment with troglitazone. These results are comparable with that of colon cancer cells (Brockman et al, 1998; Kitamura et al, 1999). Therefore, growth inhibition by PPAR $\gamma$ ligands may be, at least in part, related to cell cycle arrest at G1 phase. In MKN-7 cells, cell cycle analysis after troglitazone treatment showed an increase in S phase with decreased G1 phase. Increased $\mathrm{S}$ phase in MKN-7 is also compatible with the $\left[{ }^{3} \mathrm{H}\right]$ thymidine incorporation result of $\mathrm{MKN}-7$ which show an increase too.

To investigate other possible mechanisms of the antiproliferative effect of PPAR $\gamma$ activation, the effect of PPAR $\gamma$ ligands on cellular apoptosis was studied in gastric cancer cells. PPAR $\gamma-$ induced apoptosis has recently been demonstrated in human breast cancer (Elstner et al, 1998; Clay et al, 1999), choriocarcinoma (Keelan et al, 1999), prostate cancer (Kubota et al, 1998) and endothelial cells (Bishop-Bailey and Hla, 1999). In the present study, treatment with troglitazone resulted in an increase in the number of apoptotic cells. Thus, apoptosis and cell cycle arrest are possible mechanisms for the growth inhibitory effect of PPAR $\gamma$ activation.

Recent reports have indicated that PPAR $\gamma$ ligands also suppress the clonal growth of leukaemia cell lines (Asou et al, 1999; Hirase et al, 1999; Sugimura et al, 1999). In fact, differentiation therapy with all-trans retinoic acid, a ligand for RAR $\alpha$, has already become one of the standard treatments for acute promyelocytic leukaemia (APML) (Huang et al, 1998; Warrell et al, 1991). Therapy that induces apoptosis and differentiation has recently been considered as a possible alternative treatment for various neoplastic diseases other than APML.

In the present study, we have shown that activation of one of the DNA-binding nuclear receptors PPAR $\gamma$ or $\operatorname{RXR} \alpha$ has a growth suppressing effect on certain poorly differentiated gastric cancer cells. Poorly differentiated gastric cancer is frequently observed and it is the most lethal malignant neoplasm in several countries, including Japan. Therefore, therapy with potent PPAR $\gamma$ agonists may be a promising future approach for the treatment of poorly differentiated gastric cancer. Further studies will be necessary before PPAR $\gamma$ ligands can be used in patients with gastric cancer, but this nuclear receptor may provide a novel target for the treatment of gastric cancer in humans.

\section{REFERENCES}

Asou H, Verbeek W, Williamson E, Elstner E, Kubota T, Kamada N and Koeffler HP (1999) Growth inhibition of myeloid leukemia cells by troglitazone, a ligand for peroxisome proliferator activated receptor gamma, and retinoids. Int $J$ Oncol 15: 1027-1031

Bishop-Bailey D and Hla T (1999) Endothelial cell apoptosis induced by the peroxisome proliferator-activated receptor (PPAR) ligand 15-deoxy- $\Delta^{12,14}$ prostaglandin J2. J Biol Chem 24: 17042-17048

Brockman JA, Gupta RA and Dubois RN (1998) Activation of PPAR $\gamma$ leads to inhibition of anchorage-independent growth of human colorectal cancer cells. Gastroenterology 115: 1049-1055

Chawla A, Schwarz EJ, Dimaculangan DD and Lazar MA (1994) Peroxisome proliferator-activated receptor (PPAR) $\gamma$ : adipose-predominant expression and induction early in adipocyte differentiation. Endocrinology 135: 798-800

Clay CE, Namen AW, Atsumi G, Willingham MC, High KP, Kute TE, Trimboli AJ, Fonteh AN, Dawson PA and Chilton FH (1999) Influence of J series prostaglandins on apoptosis and tumorigenesis of breast cancer cells. Carcinogenesis 20: 1905-1911

Demetri GD, Fletcher CDM, Mueller E, Sarraf P, Naujoks RN, Campbell N, Spiegelman BM and Singer S (1999) Induction of solid tumor differentiation by the peroxisome proliferator-activated receptor $\gamma$ ligand troglitazone in patients with liposarcoma. Proc Natl Acad Sci USA 96: 3951-3956

Elstner E, Muller C, Koshizuka K, Asou H, Williamson EA, Park D, Shintaku P, Said JW, Heber D and Koeffler HP (1998) Ligands for peroxisome proliferatoractivated receptor $\gamma$ and retinoic acid receptor inhibit growth and induce apoptosis of human breast cancer cells in vitro and in BNX mice. Proc Natl Acad Sci USA 95: 8806-8811

Forman BM, Tontonoz P, Chen J, Brun RP, Spiegelman BM and Evans RM (1995) 15-Deoxy- $\Delta^{12,14}$-prostaglandin $\mathrm{J} 2$ is a ligand for the adipocyte differentiation factor PPAR $\gamma$. Cell 83: 803-812

Hirase N, Yanase T, Mu YM, Muta K, Umemura T, Takayanagi R and Nawata H (1999) Thiazolidinedione induces apoptosis and monocytic differentiation in the promyelocytic leukemia cell line HL60. Oncology 57(Suppl 2): 17-25

Huang ME, Ye YC, Chen SR, Chai JR, Lu JX, Zhoa L, Gu LJ and Wang ZY (1988) Use of all-trans retinoic acid in the treatment of acute promyelocytic leukemia. Blood 72: 567-572

Hu E, Tontonoz P and Spiegelman BM (1995) Transdifferentiation of myoblasts by the adipogenic transcription factors PPAR $\gamma$ and $\mathrm{C} / \mathrm{EBPa}$. Proc Natl Acad Sci USA 92: 9856-9860

Keelan JA, Sato TA, Marvin KW, Lander J, Gilmour RS and Mitchell MD (1999) 15-Dexoy- $\Delta^{12,14}$-prostaglandin J2, a ligand for peroxisome proliferator-activated receptor $\gamma$, induces apoptosis in JEG3 choriocarcinoma cells. Biochem Biophys Res Commun 262: 579-585

Kitamura S, Miyazaki Y, Shinomura Y, Kondo S, Kanayama S and Mastuzawa Y (1999) Peroxisome proliferator-activated receptor $\gamma$ induces growth arrest and differentiation markers of human colon cancers. Jpn J Cancer Res 90: 75-80 
Kliewer SA, Lenhard JM, Willson TM, Patel I, Morris DC and Lehmann JM (1995) A prostaglandin $\mathrm{J} 2$ metabolite binds peroxisome proliferator-activated receptor $\gamma$ and promotes adipocyte differentiation. Cell 83: 813-819

Kubota T, Koshizuka K, Asou H, Williamson EA, Said JW, Holded S, Miyoshi I and Koeffler HP (1998) Ligand for peroxisome proliferator-activated receptor $\gamma$ (troglitazone) has potent antitumor effect against human prostate cancer both in vitro and in vivo. Cancer Res 58: 3344-3352

Lefebvre AM, Chen I, Desreumaux P, Najib J, Fruchart JC, Geboes K, Briggs M, Heyman R and Auwerx J (1998) Activation of the peroxisome proliferatoractivated receptor $\gamma$ promotes the development of colon tumors in $\mathrm{C} 57 \mathrm{BL} / 6 \mathrm{~J}$ APCmin/+mice. Nat Med 4: 1053-1057

Lehmann JM, Lenhard JM, Oliver BB, Ringold GM and Kliewer SA (1997) Peroxisome proliferator-activated receptor $\alpha$ and $\gamma$ are activated by indomethacin and other non-steroidal anti-inflammatory drugs. J Biol Chem 272: $3406-3410$

Mukherjee R, Davles PJA, Cromble DL, Bischoff ED, Cesario RM, Jow L, Hamann LG, Boehm MF, Mondon CE, Nadzan AM, Paternitl JRJR and Heyman RA (1997) Sensitization of diabetic and obese mice to insulin by retinoid X receptor agonists. Nature 386: $407-410$

Pelton PD, Zhou L, Demarest KT and Burris TP (1999) PPAR $\gamma$ activation induces the expression of the adipocyte fatty acid binding protein gene in human monocytes. Biochem Biophys Res Commun 261: 456-458

Saez E, Tontonoz P, Nelson MC, Alvarez JGA, Ming U-T, Baird SM, Thomazy VA and Evans RM (1998) Activators of the nuclear receptor PPAR $\gamma$ enhance colon polyp formation. Nat Med 4: 1058-1061
Sarraf P, Mueller E, Jones D, King FJ, Deangelo DJ, Partridge JB, Holden SA, Chen LB, Singer S, Fletcher C and Spiegelman BM (1998) Differentiation and reversal of malignant changes in colon cancer through PPAR $\gamma$. Nat Med $\mathbf{4}$ 1046-1052

Sugimura A, Kiriyama Y, Nochi H, Tsuchiya H, Tamoto K, Sakurada Y, Ui M and Tokumitsu Y (1999) Troglitazone suppresses cell growth of myeloid leukemia cell lines by induction of $\mathrm{p} 21$ Waf1/Cip 1 cyclin-dependent kinase inhibitor. Biochem Biophys Res Commun 261: 833-837

Takahashi N, Okumura T, Motomura W, Fujimoto Y, Kawabata I and Kohgo Y (1999) Activation of PPAR $\gamma$ inhibits cell growth and apoptosis in human gastric cancer cells. FEBS Lett 455: 135-139

Tontonoz P, Hu E and Spiegelman BM (1994) Stimulation of adipogenesis in fibroblasts by PPAR $\gamma 2$, a lipid-activated transcription factor. Cell 79: 1147-1156

Tontonoz P, Singer S, Forman AM, Sarraf P, Fletcher JA, Fletcher CDM, Brun RP, Mueller E, Altiok S, Oppenheim H, Evans RM and Spiegelman BM (1997). Terminal differentiation of human liposarcoma cells induced by ligands for peroxisome proliferator-activated receptor $\gamma$ and the retinoid $\mathrm{X}$ receptor. Proc Natl Acad Sci USA 94: 237-241

Tontonoz P, Nagy L, Alvarez JGA, Thomazy VA and Evans RM (1998) PPAR $\gamma$ promotes monocyte/macrophage differentiation and uptake of oxidized LDL. Cell 93: 241-252

Warrell RP, Frankel SR, Miller WHJR, Scheinberg DA, Itri LM, Hittelman WN, Vyas R, Andreeff M, Tafuri A, Jakubowski A, Gabrilove J, Gordon MS and Dmitrovsky E (1991) Differentiation therapy of acute promyelocytic leukemia with tretinoin (all-trans-retinoic acid). N Engl J Med 324: 1385-1393 